\title{
ANALISIS PENGARUH MODEL HOT-FIT TERHADAP PEMANFAATAN SISTEM INFORMASI KINERJA ANGGARAN
}

\author{
Naretha Kawadha Pasemah Gumay $^{* 1}$, Rahmat Gernowo ${ }^{2}$, Oky Dwi Hurhayati ${ }^{3}$ \\ ${ }^{1,2}$ Program Studi Magister Sistem Informasi, Sekolah Pascasarjana, Universitas Diponegoro \\ ${ }^{3}$ Departemen Teknik Komputer, Fakultas Teknik, Universitas Diponegoro \\ Email: ${ }^{1}$ narethakawadhapasema@students.undip.ac.id, ${ }^{2}$ rahmatgernowo@lecturer.undip.ac.id, \\ 3 okydwin@gmail.com \\ *Penulis Korespondensi
}

(Naskah masuk: 24 Maret 2020, diterima untuk diterbitkan: 15 Mei 2020)

\begin{abstract}
Abstrak
Sistem informasi kinerja anggaran digunakan untuk memantau kinerja anggaran di fakultas Universitas Sriwijaya berdasarkan Indikator Kinerja Pelaksanaan Anggaran. Analisis pengaruh sistem menggunakan model Human, Organization, and Technology-Fit (HOT-Fit) dilakukan untuk menganalisis keberhasilan penerapan sistem, ketiga komponen penilaian tersebut mendapatkan net benefit berupa dampak sistem. Model HOT-Fit dalam penelitian ini memiliki delapan variabel, yaitu System Development (SD), System Use (SU), User Satisfaction (US), Structure (STR), Environment (LO), System Quality (SQ), Information Quality (IQ), dan Service Quality (SEQ). Jumlah sampel responden adalah 59, teknik analisis menggunakan PLS-SEM yang terdapat dua tahapan analisis. Pertama, measurement model digunakan untuk menguji reliabilitas dan validitas. Reliabilitas diambil dari nilai loading factor dan composite reliability yang memiliki nilai di atas 0,7 , sedangkan validitas memiliki nilai di atas 0,5 dari AVE dan cross-loading indikator dimana nilai konstruk semua variabel lebih tinggi dari korelasi konstruk blok lain. Kedua, structural model diambil dari hasil uji path coefficient, coefficient of determination, dan t-test. Path coefficient terdapat empat jalur yang tidak signifikan (LO $\rightarrow \mathrm{SD}$, $\mathrm{LO} \rightarrow \mathrm{SU}, \mathrm{SD} \rightarrow \mathrm{SU}$, dan $\mathrm{SQ} \rightarrow \mathrm{US}$ ) memiliki nilai dibawah 0,1. Coefficient of determination terdapat enam variabel dengan tingkat kuat dengan nilai sekitar 0,670 (LO, SD, SU, US, IQ, dan SQ) dan satu tingkat moderat dengan nilai sekitar 0,333 (STR). T-test terdapat dua belas hipotesis yang diterima dari sembilan belas hipotesis yang memiliki nilai lebih besar dari 1,96. Faktor-faktor yang paling kuat memengaruhi keberhasilan sistem adalah SU, US, STR, LO, dan SEQ.
\end{abstract}

Kata kunci: analisis pengaruh, HOT-Fit, sistem informasi kinerja anggaran, PLS-SEM

\section{ANALYSIS OF HOT-FIT MODEL IMPACT ON BUDGETING PERFORMANCE INFORMATION SYSTEM}

\begin{abstract}
Budgeting performance information system is used to monitor budget performance at the faculty of Sriwijaya University based on Budget Implementation Performance Indicator. An analysis using Human, Organization, and Technology-Fit (HOT-Fit) model is conducted to analize the system implementation, those components get a net benefit as impact. The studied model has eight variables, System Development (SD), System Use (SU), User Satisfaction (US), Structure (STR), Environment (LO), System Quality (SQ), Information Quality (IQ), and Service Quality (SEQ). With 59 respondents, two stage of PLS-SEM technique is used for analysis. Firstly, measurement models for reliability and validity. Reliability is set from loading factor and composite reliability which values above 0.7, while the validity from AVE which values above 0.5 and cross-loading indicators where the block constructs from all variables higher than the correlation with others. Secondly, structural model, taken from the path coefficient, coefficient of determination, and t-test, that have four insignificant pathways (LO $\rightarrow S D$, $L O \rightarrow S U, S D \rightarrow S U, S Q \rightarrow U S)$ that values below 0,1. The Coefficient of determination has six variables with strong levels which values about 0,670 (LO,SD, SU, US, IQ, and SQ) and one moderate levels which values about 0,333 (STR). The T-test contained twelve accepted hypotheses from the nineteen hypotheses which values bigger than 1,96. The factors that strongly affect the success of the system are SU, US, STR, LO, and SEQ.
\end{abstract}

Keywords: influence analysis, HOT-Fit, budgeting performance information system, PLS-SEM 


\section{PENDAHULUAN}

Sistem informasi kinerja anggaran digunakan untuk memantau kinerja anggaran di fakultas Universitas Sriwijaya berdasarkan Indikator Kinerja Pelaksanaan Anggaran (IKPA) yang bertujuan dalam menjamin output delivery demi kelancaran pelaksanaan anggaran, mendukung manajemen kas, dan meningkatkan kualitas laporan keuangan. Salah satu wujud pengelolaan keuangan yang baik adalah mampu merencanakan kebutuhannya dalam satu tahun anggaran dan melaksanakan dengan tepat apa yang telah direncanakannya (Muda \& Saputra, 2017). Evaluasi terhadap sistem informasi kinerja anggaran harus dilakukan, hal ini untuk melihat seberapa besar kontribusi yang diharapkan terhadap pemanfaatan dari sistem tersebut dalam menjamin output delivery, untuk mengetahui keberhasilan penerapan sistem maka dilakukan analisis pengaruh menggunakan model Human, Organization, and Technology (HOT-Fit).

Penelitian ini bertujuan untuk menganalisis pengaruh model HOT-Fit terhadap pemanfaatan sistem informasi kinerja anggaran dalam menjamin output delivery. Gambar 1 merupakan tampilan dari sistem informasi kinerja anggaran yang dibangun.

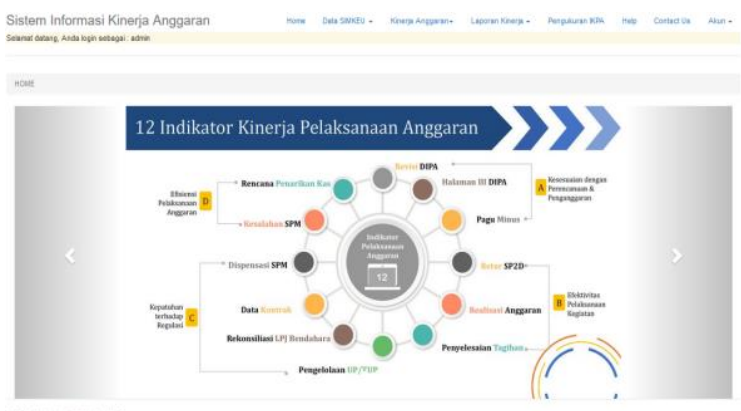

Gambar 1. Tampilan Sistem Informasi Kinerja Anggaran

Analisis pengaruh model HOT-Fit didapat dari kuesioner yang telah dibagikan sebanyak 59 responden (pimpinan dan staf di bagian keuangan pada fakultas-fakultas Universitas Sriwijaya). Kuesioner dibuat dengan mengadopsi delapan variabel, yaitu System Development (SD), System Use (SU), User Satisfaction (US), Structure (STR), Environment (LO), System Quality (SQ), Information Quality (IQ), dan Service Quality (SEQ) (Yusof, 2015).

Penelitian terdahulu melakukan evaluasi faktor-faktor yang dapat memengaruhi Electronic Medical Record (EMR) menggunakan HOT-Fit model (Erlirianto, Ali, \& Herdiyanti, 2015) dan mengidentifikasi faktor-faktor yang memengaruhi keberhasilan SIRS (Rumambi, Santoso, \& Setyohadi, 2017). Analisis mengukur kesuksesan web portal menggunakan metode DeLone and McLean Model for IS Success, dimana kualitas sistem mempunyai pengaruh yang kuat terhadap kepuasan pengguna daripada kualitas informasi dan kualitas layanan (Al-Debei, Jalal, \& Al-Lozi, 2013).
Beberapa pengujian menggunakan metode DeLone and McLean Model for IS Success untuk menguji keberhasilan sistem (Roky \& Meriouh, 2015; Monika \& Gaol, 2017; Zuama dkk., 2017). Metode lainnya menggunakan Single Ease Questionnaire (SEQ) dengan usability terhadap aplikasi fitness berbasis mobile dan memiliki tujuh kriteria yaitu effectiveness, efficiency, satisfaction, memorability, errors, learnability, dan cognitive load. Hasil pengujian yang dilakukan menyatakan bahwa aplikasi gagal memenuhi usability dikarenakan kesulitan dalam penggunaan aplikasi tersebut (Alturki \& Gay, 2017). Peningkatan fokus pada user interface dapat meningkatkan penggunaan aplikasi oleh pengguna berusia senja berdasarkan hasil dari komparasi control group dan experiment group (Kalimullah \& Sushmitha, 2017). Metode User Experience Questionnaire (UEQ) untuk mengevaluasi desain interface dengan tujuan meningkatkan pengalaman user (Santoso, Virginia, $\&$ Susanto, 2017). Metode evaluasi heuristik website berbasis framework sirius (Marthasari \& Hayatin, 2020) dan menggunakan usability (Khajouei, Gohari, \& Mirzaee, 2018). Evaluasi sistem informasi UKM menggunakan metode webqual (Mirza \& Putra, 2019).

Penjabaran di atas, diketahui terdapat beberapa penelitian evaluasi sistem yaitu metode DeLone and McLean Model for IS Success, SEQ, usability, UEQ, heuristik, webqual, dan HOT-Fit, masing-masing metode menggunakan kriteria yang berbeda-beda. Penelitian ini memiliki delapan variabel yaitu SD, SU, US, STR, LO, SQ, IQ, dan SEQ. Hasil dari delapan variabel penilaian akan mendapatkan net benefit berupa dampak sistem secara keseluruhan (Yusof, 2015). Teknik analisis menggunakan PLSSEM yang terdiri dari dua tahapan analisis yaitu measurement model dan structural model.

\section{METODE PENELITIAN}

Penelitian analisis pengaruh model HOT-Fit terhadap pemanfaatan sistem informasi kinerja anggaran dilakukan beberapa tahapan yang dibutuhkan agar penelitian ini dapat berjalan sesuai dengan yang diharapkan dan memperoleh hasil yang optimal terhadap evaluasi dari sistem yang dibangun.

\subsection{Prosedur Penelitian}

Prosedur penelitian ini terdiri dari dari lima tahapan yaitu tinjauan literatur, theoretical background, penyebaran dan pengumpulan kuesioner, analisis dan identifikasi model, dan kesimpulan, seperti yang ditunjukkan pada Gambar 2 . 


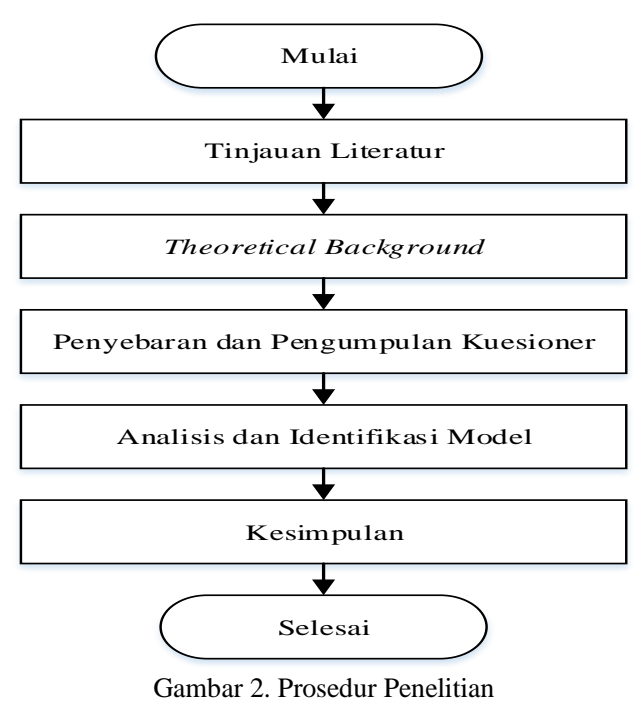

Prosedur penelitian terdiri dari lima tahapan yaitu pertama, tinjauan literatur digunakan untuk menghimpun informasi yang sesuai dengan objek penelitian. Kedua, theoretical background membahas teori tentang model evaluasi sistem informasi kinerja anggaran menggunakan model HOT-Fit. Ketiga, penyebaran dan pengumpulan kuesioner kepada 59 responden terkait bidang keuangan di universitas sriwijaya. Keempat, tahapan analisis dan identifikasi model menggunakan software PLS-SEM dengan dua tahapan pengujian yaitu measurement model dan structural model. Kelima, membuat kesimpulan dari hasil analisis dan identifikasi model.

\subsection{Model HOT-Fit}

Model penelitian menggunakan HOT-Fit untuk mengidentifikasi faktor-faktor yang memengaruhi antara human (manusia), organisation (organisasi), dan technology (teknologi) (Yusof, 2015). Kerangka HOT-Fit ditunjukkan pada Gambar 3. Komponen human, organization, dan technology memiliki beberapa faktor yang memengaruhi masing-masing komponen.
Komponen human menilai sebuah sistem informasi dari aspek system development, system use, dan user satisfaction. System development menjelaskan tentang proses dan masalah dalam pengembangan sistem. Faktor yang memengaruhi komponen system development yaitu requirement, design, implementation, training, dan maintenance. System Use berkaitan dengan konsumsi penerima output sistem informasi terhadap tujuan penggunaan, tingkat penggunaan, dan harapan. User satisfaction berkaitan dengan persepsi kebermanfaatan, kepuasan secara keseluruhan, dan kenyamanan terhadap penggunaan sistem yang dipengaruhi oleh karakteristik personel.

Komponen organisation menilai sebuah sistem informasi dari spek structure dan environment. Structure berkaitan dengan karakteristik, budaya, kebijakan, dan tujuan pencapaian dalam organisasi. Environment berkaitan dengan lingkungan internal, sumber daya yang terlibat, pengaruh pihak luar, dan keberadaan pihak yang mengelola.

Komponen technology menilai sebuah sistem informasi dari aspek system quality, information quality, dan service quality. System quality berkaitan dengan memudahkan penggunaan, kemampuan mengakses sistem, kemampuan sistem mudah dipelajari, kualitas sistem, tingkat dukungan teknis, dan keamanan sistem. Information quality berkaitan dengan ketepatan waktu, teratur, ketepatan informasi, kelengkapan, kesesuaian terhadap data masuk, dan keterkaitan. Service quality berkaitan dengan dukungan teknis, kemampuan respon, kemampuan memahami kebutuhan, dan kemampuan tindak lanjut pelayanan terhadap sistem. Hasil penilaian dari komponen tersebut akan mendapatkan net benefit berupa dampak sistem informasi secara keseluruhan. Net benefit dinilai berdasarkan efisiensi, efektivitas, dan kualitas pengambilan keputusan. Tabel 1 menjelaskan tentang hipotesis penelitian yang telah ditunjukkan pada Gambar 3 .

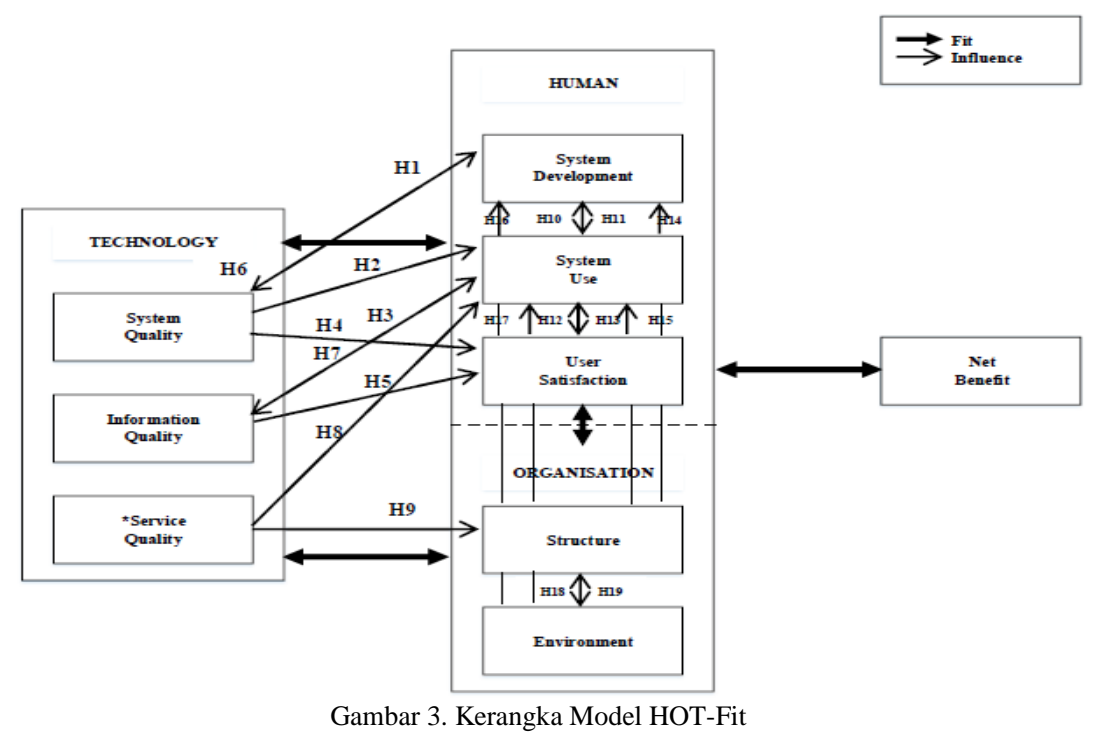


Tabel 1. Hipotesis Penelitian Model HOT-Fit

\begin{tabular}{|c|c|}
\hline Hipotesis & Deskripsi \\
\hline $\mathrm{H} 1$ & $\begin{array}{l}\text { Apakah System Quality mempunyai pengaruh } \\
\text { signifikan terhadap System Development }\end{array}$ \\
\hline $\mathrm{H} 2$ & $\begin{array}{l}\text { Apakah System Quality mempunyai pengaruh } \\
\text { signifikan terhadap System Use }\end{array}$ \\
\hline $\mathrm{H} 3$ & $\begin{array}{l}\text { Apakah Information Quality mempunyai } \\
\text { pengaruh signifikan terhadap System Use }\end{array}$ \\
\hline $\mathrm{H} 4$ & $\begin{array}{l}\text { Apakah System Quality mempunyai pengaruh } \\
\text { signifikan terhadap User Satisfaction }\end{array}$ \\
\hline H5 & $\begin{array}{l}\text { Apakah Information Quality mempunyai } \\
\text { pengaruh signifikan terhadap User Satisfaction }\end{array}$ \\
\hline H6 & $\begin{array}{l}\text { Apakah System Development mempunyai } \\
\text { pengaruh signifikan terhadap System Quality* }\end{array}$ \\
\hline $\mathrm{H} 7$ & $\begin{array}{l}\text { Apakah System Use mempunyai pengaruh } \\
\text { signifikan terhadap Information Quality* }\end{array}$ \\
\hline H8 & $\begin{array}{l}\text { Apakah Service Quality mempunyai pengaruh } \\
\text { signifikan terhadap System Use }\end{array}$ \\
\hline H9 & $\begin{array}{l}\text { Apakah Service Quality mempunyai pengaruh } \\
\text { signifikan terhadap Structure }\end{array}$ \\
\hline H10 & $\begin{array}{l}\text { Apakah System Development mempunyai } \\
\text { pengaruh signifikan terhadap System Use }\end{array}$ \\
\hline H11 & $\begin{array}{l}\text { Apakah System Use mempunyai pengaruh } \\
\text { signifikan terhadap System Development* }\end{array}$ \\
\hline H12 & $\begin{array}{l}\text { Apakah System Use mempunyai pengaruh } \\
\text { signifikan terhadap User Satisfaction }\end{array}$ \\
\hline H13 & $\begin{array}{l}\text { Apakah User Satisfaction mempunyai pengaruh } \\
\text { signifikan terhadap System Use* }\end{array}$ \\
\hline H14 & $\begin{array}{l}\text { Apakah Structure mempunyai pengaruh } \\
\text { signifikan terhadap System Development }\end{array}$ \\
\hline H15 & $\begin{array}{l}\text { Apakah Structure mempunyai pengaruh } \\
\text { signifikan terhadap System Use }\end{array}$ \\
\hline H16 & $\begin{array}{l}\text { Apakah Environment mempunyai pengaruh } \\
\text { signifikan terhadap System Development }\end{array}$ \\
\hline H17 & $\begin{array}{l}\text { Apakah Environment mempunyai pengaruh } \\
\text { signifikan terhadap System Use }\end{array}$ \\
\hline H18 & $\begin{array}{l}\text { Apakah Structure mempunyai } \\
\text { signifikan terhadap Environment }\end{array}$ \\
\hline H19 & $\begin{array}{l}\text { Apakah Environment mempunyai } \\
\text { signifikan terhadap Structure* }\end{array}$ \\
\hline
\end{tabular}

\subsection{Penyebaran dan Pengumpulan Kuesioner}

Pengambilan sampel kuesioner menggunakan teknik multi-stage purposive sampling, yang terdiri dari dua tahapan. Pertama, tahapan purposive sampling digunakan untuk memilih populasi, yang mempunyai kriteria berdasarkan pengalaman dalam bidang keuangan dan menggunakan aplikasi Sistem Informasi Keuangan (SIMKEU). Kedua, tahapan accidental sampling dimana responden yang dipilih kebetulan ada dan pertemuannya tidak direncanakan.

Populasi penelitian ini adalah seluruh pimpinan dan staf bagian keuangan di sepuluh fakultas Universitas Sriwijaya yang terdiri dari wakil dekan bidang umum dan keuangan (pimpinan keuangan fakultas), kasubag umum dan keuangan, dan staf keuangan atau staf anggaran dan bendahara pengeluaran pembantu sejumlah 68 orang. Rumus slovin digunakan untuk pengambilan sampel seperti yang ditunjukkan pada persamaan rumus 1 dengan Margin of Error sebesar 5\%.

$\mathfrak{n}=\frac{\mathrm{N}}{\left(1+\left(\mathrm{N} x e^{2}\right)\right)}$
Pada persamaan (1), $\mathrm{n}$ merupakan ukuran sampel. $\mathrm{N}$ adalah ukuran populasi, sedangkan e merupakan Margin of Error, berdasarkan rumus pada persamaan (1), maka didapat hasil perhitungan sesuai dengan Margin of Error 5\%, sebagai berikut:

$$
\begin{aligned}
\mathfrak{n} & =\frac{68}{\left(1+\left(68 \times 5 \%^{2}\right)\right)} \\
& =\frac{68}{(1+(68 \times 0,0025))} \\
& =\frac{68}{(1+(0,17))} \\
& =\frac{68}{1,17} \\
& =58,11 \\
\mathfrak{n} & =58 \text { responden }
\end{aligned}
$$

Data kuesioner dilakukan penyebaran kuesioner berdasarkan hasil rumus slovin, mengatakan bahwa 59 reponden yang diperoleh dinyatakan valid dan dijadikan sampel dalam penelitian. Pernyataan kuesioner memiliki 40 empat puluh item pernyataan dengan tiga komponen (human, organization, dan technology) dan delapan variabel yaitu SD, SU, US, STR, LO, SQ, IQ, dan SEQ, hasil penilaian dari tiga komponen tersebut akan menghasilkan net benefit berupa efisiensi, efektivitas, dan kualitas pengambilan keputusan. Pemilihan penilaian menggunakan skala likert 5 poin yang berarti 1 artinya Sangat Tidak Setuju, 2 artinya Tidak Setuju, 3 artinya Cukup, 4 artinya Setuju, dan 5 artinya Sangat Setuju.

\begin{tabular}{|c|c|}
\hline Variabel & $\begin{array}{l}\text { Fungsi } \\
\end{array}$ \\
\hline SQ1 - SQ7 & $\begin{array}{l}\text { Pernyataan untuk mengecek aspek System } \\
\text { Quality }\end{array}$ \\
\hline IQ1 - IQ6 & $\begin{array}{l}\text { Pernyataan untuk mengecek aspek } \\
\text { Information Quality }\end{array}$ \\
\hline SEQ1 - SEQ4 & $\begin{array}{l}\text { Pernyataan untuk mengecek aspek Service } \\
\text { Quality }\end{array}$ \\
\hline SD1 - SD5 & $\begin{array}{l}\text { Pernyataan untuk mengecek aspek System } \\
\text { Development }\end{array}$ \\
\hline SU1 - SU3 & $\begin{array}{l}\text { Pernyataan untuk mengecek aspek System } \\
\text { Use }\end{array}$ \\
\hline US1 - US3 & $\begin{array}{l}\text { Pernyataan untuk mengecek aspek User } \\
\text { Satisfaction }\end{array}$ \\
\hline STR1 - STR5 & Pernyataan untuk mengecek aspek Structure \\
\hline LO1 - LO4 & $\begin{array}{l}\text { Pernyataan untuk mengecek aspek } \\
\text { Environment }\end{array}$ \\
\hline NB1 - NB3 & $\begin{array}{l}\text { Pernyataan untuk hasil penilaian Net Benefit } \\
\text { dari kedelapan variabel (SQ, IQ, SEQ, SD, } \\
\text { SU, US, STR, dan LO) }\end{array}$ \\
\hline
\end{tabular}

Implementasi model HOT-Fit digunakan untuk evaluasi sistem dan pengujian model tersebut pada sistem informasi kinerja anggaran. Kelompok dan variabel kuesioner, ditunjukkan pada Tabel 2.

Tabel 2. Kelompok dan Variabel Kuesioner

Tabel 2 menjelaskan tentang kelompok dan variabel pernyataan kuesioner yang digunakan. Pernyataan SQ1 - SQ7 berfokus pada kriteria 
System Quality. Pernyataan IQ1 - IQ6 berfokus pada kriteria Information Quality. Pernyataan SEQ1 SEQ4 berfokus pada kriteria Service Quality. Pernyataan SD1 - SD5 berfokus pada System Development. Pernyataan SU1 - SU3 berfokus pada kriteria System Use. Pernyataan US1 - US3 berfokus pada kriteria User Satisfaction. Pernyataan STR1 STR5 berfokus pada kriteria Structure. Pernyataan LO1 - LO4 berfokus pada kriteria Environment. Pernyataan NB1 - NB3 berfokus pada hasil penilaian Net Benefit dari kedelapan variabel tersebut.

Hasil jawaban kuesioner diolah menggunakan SmartPLS 3.0. SmartPLS adalah salah satu aplikasi yang digunakan dalam analisis Partial Least Square Structural Equation Modelling (PLS-SEM). Tahapan analisis menggunakan PLS-SEM terdiri dari dua tahapan pengujian yaitu measurement model dan structural model (Hair, Ringle, \& Sarstedt, 2011).

\section{HASIL DAN PEMBAHASAN}

Hasil dan pembahasan penelitian yang didapatkan berdasarkan tahapan-tahapan penelitian yang berkaitan dengan analisis pengaruh model HOT-Fit terhadap pemanfaatan sistem informasi kinerja anggaran terdiri dari data demografis, measurement model, dan structural model.

\subsection{Data Demografis}

Data demografis dimana peneliti menganalisis jawaban dari responden terkait pertanyaan profil responden dan mengetahui sistem yang dibangun.

\section{Jenis Kelamin}

Jenis kelamin responden sebanyak 35 orang berjenis kelamin perempuan dan 24 orang berjenis kelamin laki-laki, besaran persentase jenis kelamin ditunjukkan pada Gambar 4.

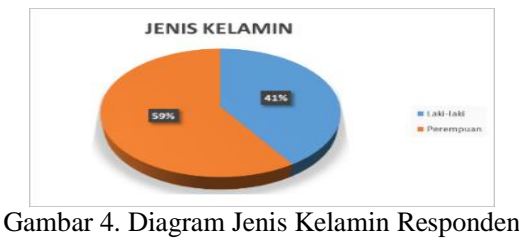

\section{Usia}

Usia responden paling banyak pada rentan usia $31-40$ tahun 30 orang, usia $41-50$ tahun 16 orang, usia $20-30$ tahun 8 orang, usia $51-60$ tahun 5 orang, dan tidak ada responden usia > 60 tahun, besaran persentase usia ditunjukkan pada Gambar 5 .

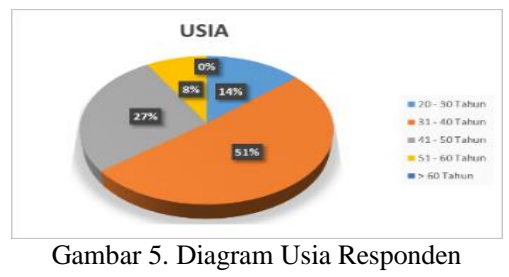

\section{Pendidikan Terakhir}

Mayoritas pendidikan terakhir responden yaitu S1 sebanyak 34 orang, DIII.IV 16 orang, S2 6 orang, SMA 3 orang, dan tidak ada pendidikan S3, besaran persentase ditunjukkan pada Gambar 6.

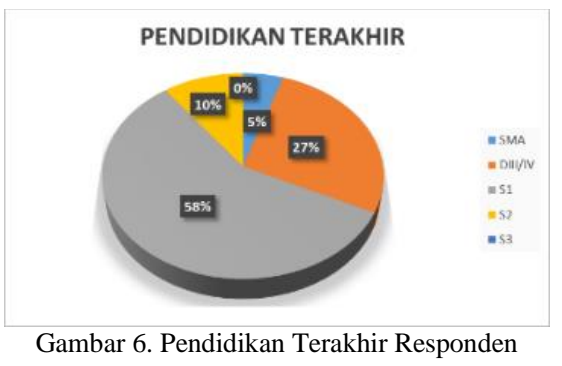

\section{Jenis Pendidikan}

Mayoritas jenis pendidikan yang paling banyak dimiliki responden berasal dari pendidikan ekonomi sebanyak 32 orang, ilmu komputer 18 orang, SMA 3 orang, teknik 2 orang, pendidikan hukum, MIPA, SDM, dan sospol masing-masing ada 1 orang, besaran persentase jenis pendidikan ditunjukkan pada Gambar 7.

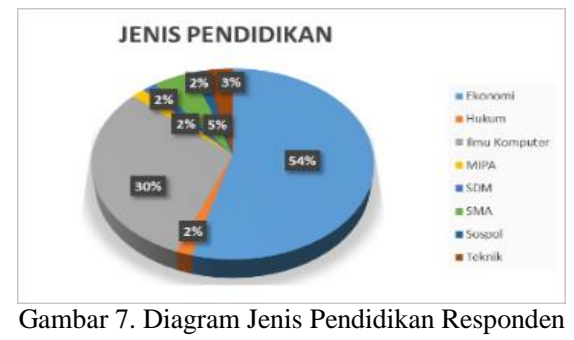

\section{Jabatan}

Mayoritas jabatan yang dimiliki paling banyak adalah staf keuangan atau staf anggaran sebanyak 38 orang, bendahara pengeluaran pembantu (BPP) 10 orang, kasubag keuangan 9 orang, dan wakil dekan bidang umum dan keuangan 2 orang, besaran persentase jabatan ditunjukkan pada Gambar 8.

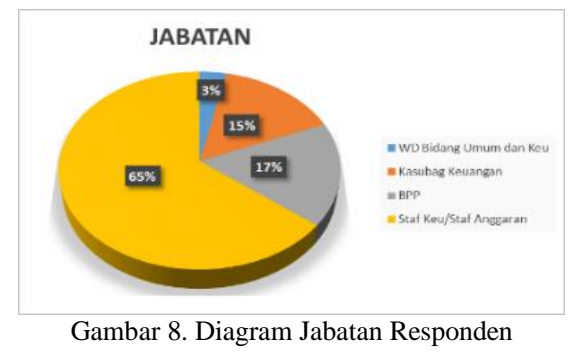

\section{Masa Kerja}

Masa kerja yang dimiliki responden $6-10$ tahun dan $11-15$ tahun 18 orang, masa kerja $1-5$ tahun 13 orang, $16-20$ tahun 8 orang, > 21 tahun 2 orang, dan tidak ada responden yang memiliki masa kerja $<1$ tahun, besaran persentase masa kerja ditunjukkan pada Gambar 9. 


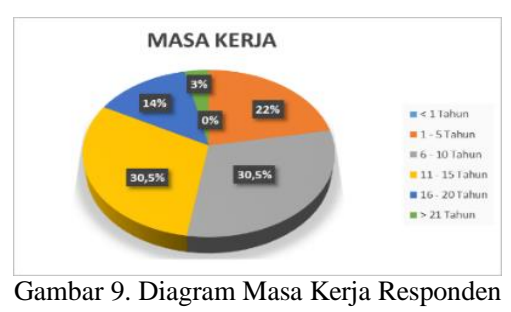

Mengetahui Sistem Informasi Kinerja Anggaran

Responden sebanyak 59 orang semuanya mengetahui sistem informasi kinerja anggaran, besaran persentase responden ditunjukkan pada Gambar 10.

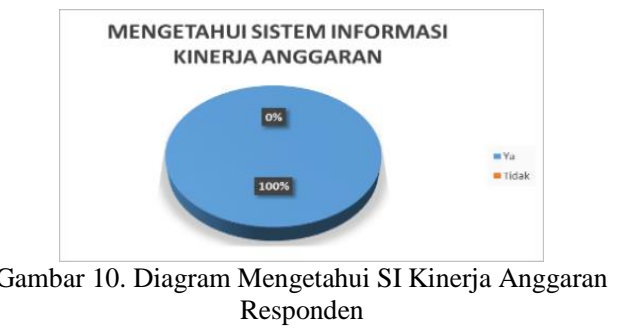

\subsection{Measurement Model}

Pengujian measurement model (outer model) digunakan untuk uji reliabilitas (Individual Item
Reliability dan Internal Consistency Reliability) dan uji validitas (Average Variance Extracted (AVE) dan Discriminant Validity) (Hair, Ringle, \& Sarstedt, 2011).

\section{Uji Individual Item Reliability}

Pengujian berdasarkan nilai standardized loading factor, yang menyatakan bahwa besarnya korelasi pada setiap item pengukuran terhadap variabel. Loading factor dapat dikatakan baik dan valid jika mempunyai nilai di atas 0,7 , dikatakan cukup jika nilai antara $0,5-0,6$, sedangkan untuk nilai $0,4-0,5$ akan dilakukan pertimbangan apabila nilai composite reliability berada pada batas aman dan indikator bisa dihapus untuk meningkatkan nilai tersebut (Hair, Ringle, \& Sarstedt, 2011). Hasil loading factor ditunjukkan pada Tabel 3. Hasil uji validitas pada Tabel 3 masih terlihat indikator yang belum valid, karena memiliki nilai loading factor berada di bawah 0,7 (indikator IQ6, LO4, SEQ4, SQ5, dan SQ6). Indikator variabel tersebut harus dihapus dan dilakukan PLS Algorithm kembali untuk memperoleh nilai loading factor yang menunjukkan semua indikator variabel valid.

\begin{tabular}{|c|c|c|c|c|c|c|c|c|}
\hline & LO & IQ & $\begin{array}{l}\text { SEQ } \\
\end{array}$ & $\begin{array}{l}\text { STR } \\
\end{array}$ & SD & SQ & SU & US \\
\hline IQ1 & & 0,859 & & & & & & \\
\hline IQ2 & & 0,838 & & & & & & \\
\hline IQ3 & & 0,816 & & & & & & \\
\hline IQ4 & & 0,841 & & & & & & \\
\hline IQ5 & & 0,870 & & & & & & \\
\hline IQ6 & & 0,581 & & & & & & \\
\hline LO1 & 0,826 & & & & & & & \\
\hline LO2 & 0,850 & & & & & & & \\
\hline LO3 & 0,757 & & & & & & & \\
\hline LO4 & 0,447 & & & & & & & \\
\hline SD1 & & & & & 0,711 & & & \\
\hline SD2 & & & & & 0,877 & & & \\
\hline SD3 & & & & & 0,846 & & & \\
\hline SD4 & & & & & 0,805 & & & \\
\hline SD5 & & & & & 0,756 & & & \\
\hline SEQ1 & & & 0,861 & & & & & \\
\hline SEQ2 & & & 0,898 & & & & & \\
\hline SEQ3 & & & 0,827 & & & & & \\
\hline SEQ4 & & & 0,155 & & & & & \\
\hline SQ1 & & & & & & 0,747 & & \\
\hline SQ2 & & & & & & 0,814 & & \\
\hline SQ3 & & & & & & 0,738 & & \\
\hline SQ4 & & & & & & 0,824 & & \\
\hline SQ5 & & & & & & 0,400 & & \\
\hline SQ6 & & & & & & 0,634 & & \\
\hline SQ7 & & & & & & 0,740 & & \\
\hline STR1 & & & & 0,802 & & & & \\
\hline STR2 & & & & 0,775 & & & & \\
\hline STR3 & & & & 0,775 & & & & \\
\hline STR4 & & & & 0,807 & & & & \\
\hline STR5 & & & & 0,745 & & & & \\
\hline SU1 & & & & & & & 0,853 & \\
\hline SU2 & & & & & & & 0,932 & \\
\hline SU3 & & & & & & & 0,882 & \\
\hline US1 & & & & & & & & 0,886 \\
\hline US2 & & & & & & & & 0,865 \\
\hline US3 & & & & & & & & 0,888 \\
\hline
\end{tabular}




\section{Uji Internal Consistency Reliability}

Pengujian internal consistency reliability dengan melihat hasil nilai dari composite reliability (CR) dengan batas ambang diatas 0,7 (Hair, Ringle, \& Sarstedt, 2011). Hasil nilai CR menunjukkan bahwa semua variabel memenuhi syarat dan valid, karena mempunyai nilai di atas 0,7 , ditunjukkan pada Tabel 4.

\begin{tabular}{lll}
\multicolumn{2}{c}{ Tabel 4. Hasil Uji Internal Consistency Reliability } \\
\hline & CR & Cronbach's Alpha \\
\hline LO & 0,862866616 & 0,761966398 \\
IQ & 0,928484489 & 0,903664167 \\
SEQ & 0,897412568 & 0,829069098 \\
STR & 0,886439914 & 0,839867039 \\
SD & 0,899159326 & 0,858679473 \\
SQ & 0,888217086 & 0,842574019 \\
SU & 0,918951586 & 0,867151239 \\
US & 0,911015118 & 0,853631113 \\
\hline
\end{tabular}

\section{Uji Average Variance Extracted (AVE)}

Tahapan pengujian convergent validity adalah dengan melihat nilai AVE. Nilai AVE menggambarkan besaran varian atau variabel yang dapat dikandung oleh variabel laten atau konstruk. Nilai AVE minimal memiliki nilai 0,5 yang menunjukkan ukuran convergent validity baik, artinya bahwa variabel laten rata-rata dapat menjelaskan lebih dari setengah variance terhadap indikator-indikator yang dimiliki (Hair, Ringle, \& Sarstedt, 2011). Hasil dari pengujian nilai AVE terhadap semua variabel memiliki nilai di atas 0,5 , sehingga memenuhi syarat untuk digunakan, ditunjukkan pada Tabel 5.

\section{Uji Discriminant Validity}

Tahapan pengujian discriminant validity melalui pemeriksaan cross loading indikator (Subiyakto dkk., 2015). Cross loading antar indikator membandingkan korelasi indikator dengan variabelnya terhadap variabel blok lain, jika terdapat korelasi antara indikator terhadap variabelnya lebih tinggi dari korelasi variabel dengan variabel blok lain, artinya konstruk dapat memprediksi ukuran blok lebih baik dari blok lain (Hair, Ringle, \& Sarstedt, 2011). Tabel 6 menunjukkan hasil uji discriminant validity dan hasil analisis yang ditunjukkan pada Gambar 11.

\begin{tabular}{cl} 
Tabel 5. Hasil Uji Average Variance Extracted \\
\cline { 2 - 2 } & AVE \\
\hline LO & 0,677553252 \\
IQ & 0,722091096 \\
SEQ & 0,744877105 \\
STR & 0,609742221 \\
SD & 0,642015118 \\
SQ & 0,614131177 \\
SU & 0,790983011 \\
US & 0,773394547 \\
\hline
\end{tabular}

Tabel 6. Hasil Uji Discriminant Validity

\begin{tabular}{|c|c|c|c|c|c|c|c|c|}
\hline & LO & IQ & SEQ & STR & SD & SQ & SU & US \\
\hline IQ1 & 0,698 & 0,867 & 0,732 & 0,676 & 0,777 & 0,733 & 0,718 & 0,743 \\
\hline IQ2 & 0,718 & $\mathbf{0 , 8 3 8}$ & 0,699 & 0,697 & 0,762 & 0,773 & 0,722 & 0,649 \\
\hline IQ3 & 0,544 & $\mathbf{0 , 8 1 4}$ & 0,667 & 0,586 & 0,613 & 0,651 & 0,652 & 0,627 \\
\hline IQ4 & 0,694 & $\mathbf{0 , 8 5 5}$ & 0,636 & 0,687 & 0,715 & 0,780 & 0,712 & 0,725 \\
\hline IQ5 & 0,761 & 0,874 & 0,728 & 0,755 & 0,779 & 0,799 & 0,824 & 0,679 \\
\hline LO1 & 0,812 & 0,678 & 0,660 & 0,793 & 0,693 & 0,637 & 0,660 & 0,576 \\
\hline LO2 & $\mathbf{0 , 8 7 0}$ & 0,737 & 0,665 & 0,757 & 0,753 & 0,751 & 0,717 & 0,621 \\
\hline LO3 & $\mathbf{0 , 7 8 5}$ & 0,564 & 0,544 & 0,623 & 0,622 & 0,711 & 0,575 & 0,438 \\
\hline SD1 & 0,608 & 0,661 & 0,582 & 0,620 & $\mathbf{0 , 7 1 0}$ & 0,605 & 0,601 & 0,591 \\
\hline SD2 & 0,808 & 0,788 & 0,733 & 0,829 & 0,878 & 0,787 & 0,721 & 0,768 \\
\hline SD3 & 0,587 & 0,671 & 0,632 & 0,673 & 0,846 & 0,668 & 0,608 & 0,693 \\
\hline SD4 & 0,665 & 0,708 & 0,559 & 0,704 & $\mathbf{0 , 8 0 4}$ & 0,694 & 0,683 & 0,617 \\
\hline SD5 & 0,678 & 0,606 & 0,613 & 0,663 & $\mathbf{0 , 7 5 7}$ & 0,714 & 0,590 & 0,617 \\
\hline SEQ1 & 0,578 & 0,645 & $\mathbf{0 , 8 6 3}$ & 0,505 & 0,618 & 0,645 & 0,644 & 0,462 \\
\hline SEQ2 & 0,665 & 0,753 & 0,900 & 0,635 & 0,696 & 0,766 & 0,718 & 0,593 \\
\hline SEQ3 & 0,707 & 0,700 & 0,824 & 0,766 & 0,696 & 0,736 & 0,693 & 0,595 \\
\hline SQ1 & 0,612 & 0,676 & 0,568 & 0,581 & 0,631 & 0,761 & 0,668 & 0,613 \\
\hline SQ2 & 0,675 & 0,722 & 0,643 & 0,649 & 0,686 & 0,806 & 0,697 & 0,576 \\
\hline SQ3 & 0,693 & 0,658 & 0,610 & 0,641 & 0,633 & 0,770 & 0,616 & 0,544 \\
\hline SQ4 & 0,669 & 0,664 & 0,707 & 0,602 & 0,665 & $\mathbf{0 , 8 3 0}$ & 0,647 & 0,562 \\
\hline SQ7 & 0,671 & 0,721 & 0,731 & 0,753 & 0,773 & 0,748 & 0,679 & 0,648 \\
\hline STR1 & 0,671 & 0,576 & 0,548 & 0,801 & 0,653 & 0,577 & 0,647 & 0,649 \\
\hline STR2 & 0,632 & 0,539 & 0,548 & 0,774 & 0,638 & 0,623 & 0,569 & 0,569 \\
\hline STR3 & 0,686 & 0,604 & 0,637 & 0,775 & 0,750 & 0,634 & 0,600 & 0,629 \\
\hline STR4 & 0,760 & 0,784 & 0,641 & $\mathbf{0 , 8 0 7}$ & 0,749 & 0,742 & 0,686 & 0,635 \\
\hline STR5 & 0,698 & 0,610 & 0,538 & 0,746 & 0,618 & 0,644 & 0,630 & 0,460 \\
\hline SU1 & 0,671 & 0,785 & 0,650 & 0,618 & 0,641 & 0,752 & 0,854 & 0,709 \\
\hline SU2 & 0,802 & 0,791 & 0,784 & 0,813 & 0,791 & 0,790 & 0,931 & 0,728 \\
\hline SU3 & 0,639 & 0,705 & 0,690 & 0,707 & 0,706 & 0,716 & $\mathbf{0 , 8 8 1}$ & 0,684 \\
\hline US1 & 0,600 & 0,738 & 0,625 & 0,686 & 0,786 & 0,674 & 0,754 & $\mathbf{0 , 8 8 4}$ \\
\hline US2 & 0,485 & 0,710 & 0,532 & 0,589 & 0,663 & 0,658 & 0,616 & 0,867 \\
\hline US3 & 0,676 & 0,679 & 0,539 & 0,716 & 0,718 & 0,658 & 0,720 & $\mathbf{0 , 8 8 7}$ \\
\hline
\end{tabular}




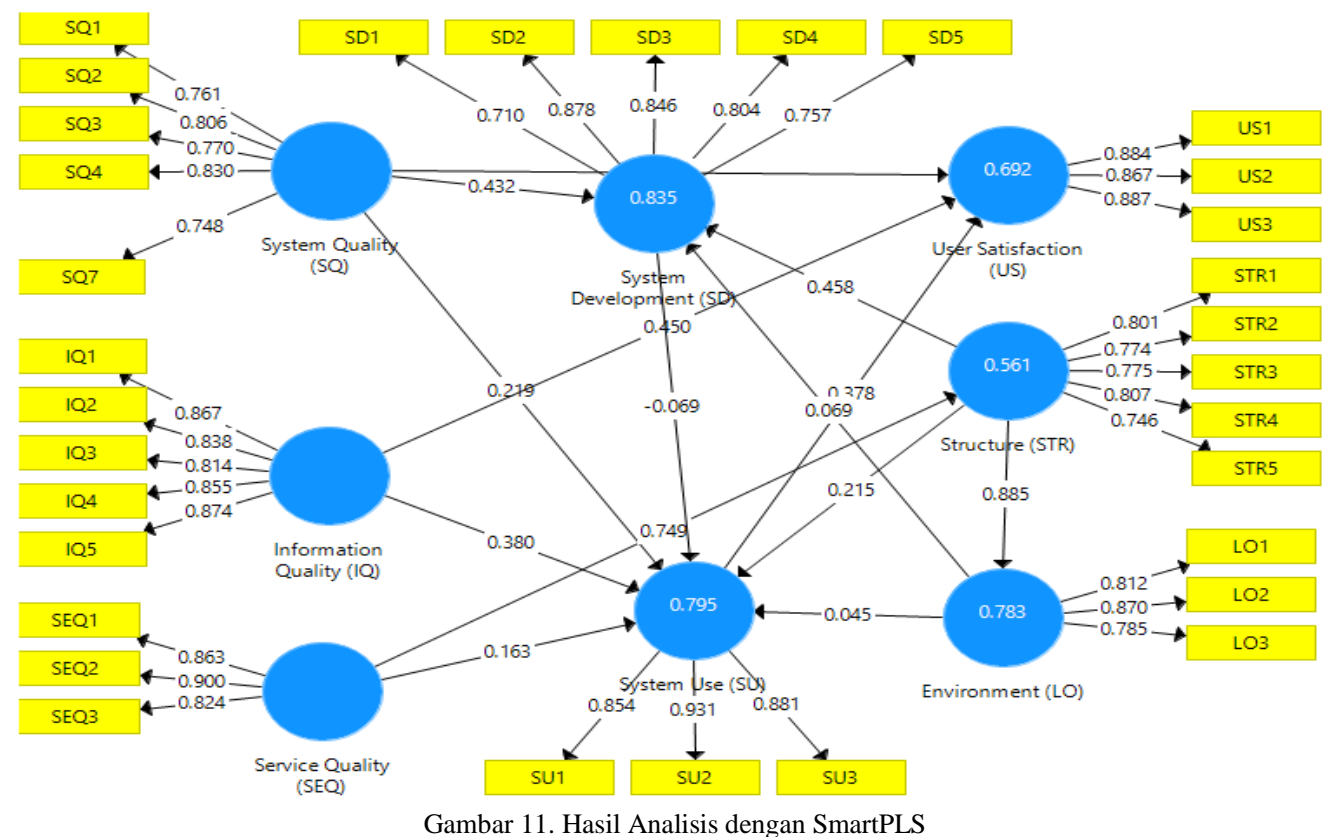

Analisis measurement model di atas menunjukkan bahwa Model I dan Model II pada penelitian ini telah memiliki karakteristik yang baik dalam pengujian statistik dan telah memenuhi syarat serta layak dilanjutkan ke tahap selanjutnya yaitu pengujian structural model walaupun dengan melakukan penghapusan terhadap lima indikator (IQ6, LO4, SEQ4, SQ5, dan SQ6). Gambar 11 memaparkan hasil dari pengujian measurement model.

\subsection{Structural Model}

Pengujian structural model (inner model) pada penelitian melakukan uji path coefficient $(\beta)$, coefficient of determination $\left(\mathrm{R}^{2}\right)$, dan $t$-test melalui bootstrapping (Hair, Ringle, \& Sarstedt, 2011).

\section{Uji Path Coefficient ( $\beta$ )}

Uji path coefficient dengan melihat nilai ambang batas di atas 0,1 yang berarti bahwa jalur atau path yang dimaksud mempunyai pengaruh (Hair, Ringle, \& Sarstedt, 2011). Hasil dari 19 jalur terdapat 4 jalur yang menunjukkan pengaruh tidak signifikan $(\mathrm{LO} \rightarrow \mathrm{SD}, \quad \mathrm{LO} \rightarrow \mathrm{SU}, \quad \mathrm{SD} \rightarrow \mathrm{SU}, \quad$ dan $\mathrm{SQ} \rightarrow \mathrm{US})$, ditunjukkan pada Tabel 7.

\section{Uji Coefficient of Determination $\left(\mathbf{R}^{2}\right)$}

Uji coefficient of determination digunakan untuk menjelaskan varian setiap target variabel yang dipengaruhi oleh variabel lain dalam sebuah model dengan memiliki standar pengukuran sekitar 0,670 artinya kuat, sekitar 0,333 artinya moderat, dan sekitar 0,190 atau di bawahnya artinya lemah (Hair, Ringle, \& Sarstedt, 2011). Tabel 8 menunjukkan hasil uji $\mathrm{R}^{2}$ pada model I dan model II, bahwa tidak ada yang berada di tingkat lemah.
Tabel 7. Path Coefficient $(\beta)$

\begin{tabular}{ll}
\multicolumn{2}{c}{ Tabel 7. Path Coefficient $(\beta)$} \\
\hline LO -> SD & 0,069 \\
LO -> SU & 0,045 \\
IQ -> SU & 0,380 \\
IQ -> US & 0,450 \\
SEQ -> STR & 0,749 \\
SEQ -> SU & 0,163 \\
STR -> LO & 0,885 \\
STR -> SD & 0,458 \\
STR -> SU & 0,215 \\
SD -> SU & $-0,069$ \\
SQ -> SD & 0,432 \\
SQ -> SU & 0,219 \\
SQ -> US & 0,038 \\
SU -> US & 0,378 \\
LO -> STR & 0,888 \\
SD -> SQ & 0,778 \\
SU -> IQ & 0,858 \\
SU -> SD & 0,803 \\
US -> SU & 0,796 \\
\hline
\end{tabular}

Tabel 8. Coefficient of Determination $\left(\mathrm{R}^{2}\right)$

\begin{tabular}{lll}
\hline & $\mathbf{R}^{2}$ Model I & $\mathbf{R}^{2}$ Model II \\
\hline LO & 0,783 & 0,455 \\
STR & 0,561 & 0,788 \\
SD & 0,835 & 0,645 \\
SU & 0,795 & 0,634 \\
US & 0,692 & - \\
IQ & - & 0,735 \\
SQ & - & 0,763 \\
\hline
\end{tabular}

\section{Uji T-test}

Uji t-test menggunakan bootstrapping, melalui uji two-tailed yang memiliki tingkat signifikansi $5 \%$ $(0,05)$ yang merupakan batas dalam menguji hipotesis apakah diterima atau ditolak. Nilai t-test lebih besar dari 1,96 artinya hipotesis diterima (Hair, Ringle, \& Sarstedt, 2011). Tabel 9 menunjukkan bahwa ada 12 hipotesis yang diterima dari 19 hipotesis dan sisanya ditolak. Tabel 10 menunjukkan hasil dari analisis structural model. 


\begin{tabular}{ll}
\multicolumn{2}{c}{ Tabel 9. Hasil Uji T-test } \\
\hline \multicolumn{1}{c}{ T-test } \\
\hline SQ -> SD & 3,431 \\
SQ -> SU & 0,855 \\
IQ -> SU & 2,345 \\
SQ -> US & 0,222 \\
IQ -> US & 2,769 \\
SD -> SQ & 6,307 \\
SU -> IQ & 26,752 \\
SEQ -> SU & 1,185 \\
SEQ -> STR & 16,857 \\
SD -> SU & 0,376 \\
SU -> SD & 17,658 \\
SU -> US & 2,143 \\
US -> SU & 19,273 \\
STR -> SD & 3,156 \\
STR -> SU & 1,233 \\
LO -> SD & 0,572 \\
LO -> SU & 0,207 \\
STR -> LO & 27,036 \\
LO -> STR & 28,976 \\
\hline
\end{tabular}

Tabel 10. Tabel Hasil Analisis Structural Model

\begin{tabular}{|c|c|c|c|c|c|}
\hline \multicolumn{2}{|c|}{ Hipotesis } & \multirow{2}{*}{$\beta$} & \multirow{2}{*}{ T-test } & \multicolumn{2}{|c|}{ Analisis } \\
\hline No & Jalur & & & $\boldsymbol{\beta}$ & T-test \\
\hline H1 & SQ -> SD & 0,432 & 3,431 & Sign & Diterima \\
\hline $\mathrm{H} 2$ & $\mathrm{SQ}->\mathrm{SU}$ & 0,219 & 0,855 & Sign & Ditolak \\
\hline H3 & IQ -> SU & 0,380 & 2,345 & Sign & Diterima \\
\hline $\mathrm{H} 4$ & SQ $->$ US & 0,038 & 0,222 & Tidak & Ditolak \\
\hline H5 & IQ -> US & 0,450 & 2,769 & Sign & Diterima \\
\hline H6 & $S D \rightarrow S Q$ & 0,778 & 6,307 & Sign & Diterima \\
\hline $\mathrm{H} 7$ & SU -> IQ & 0,858 & 26,752 & Sign & Diterima \\
\hline $\mathrm{H} 8$ & SEQ -> SU & 0,163 & 1,185 & Sign & Ditolak \\
\hline H9 & $\begin{array}{l}\text { SEQ-> } \\
\text { STR }\end{array}$ & 0,749 & 16,857 & Sign & Diterima \\
\hline H10 & $\mathrm{SD}->\mathrm{SU}$ & $-0,069$ & 0,376 & Tidak & Ditolak \\
\hline H11 & $\mathrm{SU}->\mathrm{SD}$ & 0,803 & 17,658 & Sign & Diterima \\
\hline H12 & SU $\rightarrow$ US & 0,378 & 2,143 & Sign & Diterima \\
\hline H13 & US -> SU & 0,796 & 19,273 & Sign & Diterima \\
\hline H14 & STR $\rightarrow$ SD & 0,458 & 3,156 & Sign & Diterima \\
\hline H15 & STR $\rightarrow$ SU & 0,215 & 1,233 & Sign & Ditolak \\
\hline H16 & LO -> SD & 0,069 & 0,572 & Tidak & Ditolak \\
\hline H17 & $\mathrm{LO} \rightarrow \mathrm{SU}$ & 0,045 & 0,207 & Tidak & Ditolak \\
\hline H18 & STR $->$ LO & 0,885 & 27,036 & Sign & Diterima \\
\hline H19 & LO $->$ STR & 0,888 & 28,976 & Sign & Diterima \\
\hline
\end{tabular}

\section{KESIMPULAN}

Analisis pengaruh model HOT-Fit terhadap pemanfaatan sistem informasi kinerja anggaran dan menggunakan software SmartPLS. Hasil dari analisis tersebut menghasilkan penilaian sebagai berikut:

1. Analisis measurement model digunakan untuk menguji reliabilitas dan validitas pada penelitian yang telah dilakukan dan telah mempunyai karakteristik yang baik dalam pengujian, serta memenuhi syarat dan layak untuk dilanjutkan ke tahap berikutnya, berdasarkan hasil uji internal consistency reliability mencapai nilai di atas ambang batas 0,7 , uji AVE berada diatas nilai ambang batas 0,5 , dan discriminant validity dimana nilai cross-loading semua variabel mempunyai nilai yang lebih tinggi dari korelasi terhadap konstruk blok lain, meskipun dengan melakukan penghapusan 5 indikator yaitu IQ6, LO4, SEQ4, SQ5, dan SQ6, karena mempunyai nilai loading factor di bawah 0,7 dan dilakukan
PLS algorithm kembali untuk memperoleh nilai loading factor yang menunjukkan semua indikator variabel valid.

2. Analisis structural model berdasarkan uji path coefficient ( $\beta)$, coefficient of determination $\left(\mathrm{R}^{2}\right)$, dan $t$-test melalui bootstrapping. Hasil dari path coefficient $(\beta)$ terdapat hubungan antara variabel $\mathrm{SQ} \rightarrow \mathrm{US}, \mathrm{SD} \rightarrow \mathrm{SU}, \mathrm{LO} \rightarrow \mathrm{SD}$, dan $\mathrm{LO} \rightarrow \mathrm{SU}$ yang tidak memiliki pengaruh yang signifikan dan memiliki nilai dibawah 0,1. Coefficient of determination terdapat enam variabel dengan tingkat kuat dengan nilai sekitar 0,670 (LO, SD, SU, US, IQ, dan SQ) dan satu tingkat moderat dengan nilai sekitar 0,333 (STR). T-test dapat disimpulkan bahwa terdapat 12 (dua belas) hipotesis yang diterima yang memiliki nilai lebih besar dari 1,96. Hipotesis yang ditolak sebanyak 7 (tujuh) hipotesis dan ketujuh hipotesis yang ditolak tersebut belum memenuhi nilai statistika $(t$ test) pada tahapan pengujian structural model.

3. Faktor-faktor yang paling kuat memengaruhi keberhasilan adalah SU, US, STR, LO, dan SEQ.

4. Hasil dari ketiga komponen penilaian human, organization, dan technology mendapatkan $\mathrm{Net}$ Benefit (NB) berupa dampak sistem informasi secara keseluruhan. NB sistem informasi kinerja anggaran dinilai dengan menggunakan efisiensi, efektivitas, dan kualitas pengambilan keputusan. Efisiensi dimana sistem informasi kinerja anggaran dapat mengevaluasi secara cepat dan hemat waktu terhadap pemeriksaan kinerja anggaran dari laporan perencanaan keuangan dan kegiatan yang kurang baik, pelaksanaan kegiatan yang tidak sesuai dengan jadwal, pola penyerapan anggaran tidak proporsional dan cenderung masih menumpuk di akhir tahun. Efektif dimana pengguna sistem informasi kinerja anggaran dapat melakukan sebuah perencanaan, penjadwalan, dan pengeksekusian keputusan yang tepat dan berguna dalam mengatasi permasalahan yang ada, serta suatu pekerjaan dapat dikatakan efektif jika tujuan yang telah ditetapkan sebelumnya berhasil dicapai. Sistem dapat membantu membuat sebuah keputusan yang berkualitas dan sesuai dengan tugas dan tanggung jawab adalah dimana sistem informasi kinerja anggaran dapat menampilkan informasi besaran persentase dari masingmasing indikator kinerja anggaran, sehingga membantu pengguna sistem terutama pimpinan dalam mengukur kontribusi dari program dan kegiatan tersebut. Hal ini merupakan sebuah proses untuk mewujudkan akuntabilitas kinerja dari masing-masing unit kerja dalam menciptakan good university governance. 


\section{DAFTAR PUSTAKA}

AL-DEBEI, M.M., JALAL, D., dan AL-LOZI, E., 2013. Measuring web portals success: A respecification and validation of the DeLone and McLean information systems success model. International Journal of Business Information Systems, 14(1), pp.96-133.

ALTURKI, R., dan GAY, V., 2017. Usability Testing of Fitness Mobile Application: Methodology and Quantitative Results. Academy and Industry Research Collaboration Center (AIRCC).pp.97-114.

ERLIRIANTO, L.M., ALI, A.H.N., dan HERDIYANTI, A., 2015. The Implementation of the Human, Organization, and Technology-Fit (HOT-Fit) Framework to Evaluate the Electronic Medical Record (EMR) System in a Hospital. In: Procedia Computer Science. Elsevier.pp.580-587.

HAIR, J.F., RINGLE, C.M., dan SARSTEDT, M., 2011. PLS-SEM: Indeed a silver bullet. Journal of Marketing Theory and Practice, 19(2), pp.139-152.

KALIMULLAH, K., dan SUSHMITHA, D., 2017. Influence of Design Elements in Mobile Applications on User Experience of Elderly People. In: Procedia Computer Science. Elsevier B.V.pp.352-359.

KHAJOUEI, R., GOHARI, S.H., dan MIRZAEE, M., 2018. Comparison of Two Heuristic Evaluation Methods for Evaluating the Usability of Health Information Systems. Journal of Biomedical Informatics, 58, pp.97111.

MARTHASARI, G.I., dan HAYATIN, N., 2020. Evaluasi Heuristik Website Berbasis Framework Sirius dengan Pengaturan Prioritas Menggunakan Teknik Moscow. Jurnal Teknologi Informasi dan Ilmu Komputer (JTIIK), 7(2), pp.267-274.

MIRZA, A.H., dan PUTRA, A., 2019. Evaluasi Sistem Informasi Usaha Kecil dan Menengah (UKM) Kota Palembang. Jurnal Teknologi Informasi dan Ilmu Komputer (JTIIK), 6(4), pp.397.406.

MONIKA, R., dan GAOL, F.L., 2017. Measuring the Success of E-Cargo Implementation at One of Indonesian Airlines using DeLone and McLean Model. In: IOP Conference Series: Materials Science and Engineering. Institute of Physics Publishing.pp.1-12.

MUDA, I., dan SAPUTRA, A., 2017. The Analysis of the Influencing Factors of Budget Absorption. International Journal of Economic Research The Analysis of the Influencing Factors of Budget Absorption International Journal of Economic Research, [online] 14(12),pp.287-300. Available at: <http:www.serialsjournal.com>.
ROKY, H., dan MERIOUH, Y. AL., 2015. Evaluation by Users of an Industrial Information System (XPPS) Based on the DeLone and McLean Model for IS Success. Procedia Economics and Finance, 26, pp.903-913.

RUMAMBI, F.R., SANTOSO, A.J., dan SETYOHADI, D.B., 2017. Identification of factors influencing the Success of Hospital Information System (SIRS) by Hot-Fit model 2006: A case study of RSUD Dr Samratulangi Tondano, Minahasa Regency, North Sulawesi. In: Proceedings - 2017 International Conference on Soft Computing, Intelligent System and Information Technology: Building Intelligence Through IOT and Big Data, ICSIIT 2017. Institute of Electrical and Electronics Engineers Inc.pp.202-207.

SANTOSO, N.A., VIRGINIA, G., dan SUSANTO, B., 2017. Evaluation Interface Design to Build User Experience on SInTA Service Christian Duta Wacana University Yogyakarta. TRANSFORMATIKA, [online] 15(1), pp.26-35. Available at: <www.ueqonline.org.>.

SUBIYAKTO, A., AHLAN, A.R., PUTRA, S.J., dan KARTIWI, M., 2015. Validation of information system project success model: A focus group study. SAGE Open, 5(2), pp.114.

YUSOF, M.M., 2015. A case study evaluation of a Critical Care Information System adoption using the socio-technical and fit approach. International Journal of Medical Informatics, 84(7), pp.486-499.

ZUAMA, R.A., HUDIN, J.M., PUSPITASARI, D., HERMALIANI, E.H., dan RIANA, D., 2017. Stmik, Jakarta, N.M., Bsi Bekasi, A. and Bsi Bogor, A., n.d. Quality Dimensions of DeLone-McLean Model to Measure Student's Accounting Computer Satisfaction: An Empirical Test on Accounting System Information. in International Conference on Cyber and IT Service Management. pp.1-6. 